Diabetologia 8, 211-214 (1972)

(C) by Springer-Verlag 1972

\title{
Dynamics of Ketone Body Metabolism in Diabetic Rats
}

\author{
K.H. BÄssLeR, L. HoRBACH and K. WAGNER \\ Physiologisch-chemisches Institut und Institut für Medizinische Statistik und Dokumentation der Johannes Gutenberg \\ Universität Mainz, Mainz, Germany
}

Received: January 25, 1972, accepted: February 16, 1972

\begin{abstract}
Summary. Steady state blood levels of ketone bodies during infusions of acetoacetate at various rates have been compared in healthy and diabetic rats. The characteristics of the metabolic elimination of ketone bodies from the blood are completely changed in diabetic rats. Whereas steady state levels of ketone bodies increase linearly with the infusion rate in healthy rats, this increase is exponential in diabetic animals. This difference, which is due to an impaired metabolic elimination, becomes evident only above a dosage of 50 umoles acetoacetate per $\mathrm{kg}$ per min. Chronic treatment with insulin for 4-6 days, but not acute insulin injection, restores the capacity of diabetic rats to metabolize ketone bodies at normal rates. The results are discussed with regard to the difference between the stable ketosis of starvation and the labile diabetic ketoacidosis.
\end{abstract}

Dynamique du métabolisme des corps cétoniques chez les rats diabétiques

Résumé. Les auteurs ont comparé les taux sanguins stables de corps cétoniques au cours d'infusions d'acétoacétate à différentes doses, chez des rats normaux et diabétiques. Les caractéristiques de l'élimination métabolique des corps cétoniques du sang sont complètement modifiées chez les rats diabétiques. Alors que chez les rats normaux les taux stationnaires des corps cétoniques augmentent linéairoment avec la vitesse d'infusion, cette augmentation est exponentielle chez les animaux diabétiques. Cette différence, qui est due à une élimination métabolique altérée, ne se manifeste que pour des doses d'acétoacétate supérieures à $50 \mu$ moles par $\mathrm{kg}$ et par min. Le traitement chronique par l'insuline pendant $4-6$ jours, mais non l'injection aiguë d'insuline, restaure la capacité des rats diabétiques à métaboliser les corps cétoniques à des vitesses normales. Les résultats sont discutés en ce qui concerne la différence entre la cétose stable de privation alimentaire et la céto-acidose diabétique labile.

Dynamik des Stoffwechsels der Ketokörper bei diabetischen Ratien

Zusammenfassung. Stationäre Ketonkörperspiegel im Blut bei kontinuierlicher Dauerinfusion von Acetacetat in verschiedenen Dosierungen werden bei gesunden und diabetischen Ratten vergleichend untersucht. Die metabolische Elimination der Ketonkörper aus dem Blut ist bei diabetischen Tieren völlig veründert. Während bei gesunden Ratten der stationäre Ketonkörperspiegel linear mit der Infusionsrate zunimmt, erfolgt dieser Anstieg bei diabetischen Tieren exponentiell. Dieser Unterschied, der auf eine eingeschränkte metabolische Verwertung zurückzuführen ist, wird jedoch erst über einer Dosierung von $50 \mu$ Molen Acetacetat pro $\mathrm{kg}$ und $\mathrm{min}$ sichtbar. Durch 4-6 tägige Insulinbehandlung, nicht jedoch durch akute Insulinapplikation während des Infusionsversuchs, wird bei diabetischen Ratten die normale Fähigkeit zur metabolischen Elimination von Ketonkörpern wiederhergestellt. Die Befunde werden diskutiert als eine Erklärung für den Unterschied zwischen der stabilen Hungerketose und der instabilen diabetischen Ketoacidose.

Key words: Diabetes, ketoacidosis, acetoacetate infusion, ketone body elimination, total clearance, streptozotocin, regression analysis.

\section{Introduction}

During recent years numerous investigations concerning the mechanism and regulation of ketone body metabolism $[1,2,3]$ and its physiological significance [4] have been carried out which have led to a deeper undestandingr of the complex processes involved. A number of problems, however, remained unsolved. One (of these questions) is the difference between the ketosis of starvation and diabetic ketoacidosis. The latter tends to increase and, without treatment, leads to diabetic coma, whereas starvation ketosis of the adult is stable and has an important function in caloric homeostasis [4].

We have examined the dynamies of ketone body metabolism in healthy rats [5] and found an astonishingly high turnover rate for ketone bodies. Corresponding investigations in the steady state, during continuous infusions of acetoacetate in diabetic animals, described in this paper, show completely changed turnover kinetics.

\section{Materials and Methods}

Male SIV-rats were obtained from S. Ivanovas and Co. (7967 Kisslegg, Germany). They were fed on a standard pellet diet (Altromin 1324) ad libitum and weighed $260-320 \mathrm{~g}$ before they were made diabetic by a single i.v. injection of $50 \mathrm{mg}$ streptozotocin per $\mathrm{kg}$ body weight. 8-10 days later the animals were taken into the experimental series with blood glucose levels of $400-600 \mathrm{mg} / 100 \mathrm{ml}$.

A small catheter was inserted in the inferior vena cava, exposed at laparotomy under ether anaesthesia. The abdomen was then closed carefully and the rats recovered completely from anaesthesia, while over a period of $12 \mathrm{~h} 0.75 \mathrm{~g} \cdot \mathrm{kg}^{-1} \cdot \mathrm{h}^{-1}$ of xylitol and $1 \mathrm{mg}$. $\mathrm{kg}^{-1} \cdot \mathrm{h}^{-1}$ of dimethylisoxazol was infused in a volume 
of $1.2 \mathrm{ml}$ per hour. By this treatment a balance was established between liquid supply and diuresis and the endogenous production of ketone bodies was reduced to a minimum, so that possible spontaneous changes in the course of the experiment could not be of great importance. The original levels of ketone bodies in this procedure varied between 0.09 and $0.15 \mu$ moles per $\mathrm{ml}$ blood. As described previously [5] xylitol causes a shift of the ratio $\beta$-hydroxybutyrate/acetoacetate towards the reduced form, but has no effect on the total clearance of the sum of the ketone bodies.

After $12 \mathrm{~h}$ of pre-infusion, acetoacetate was infused in varying dosages in addition to xylitol and dimethylisoxazol. At intervals of $30 \mathrm{~min}$, blood samples were drawn from the tip of the tail for the enzymatic determination of $\mathbf{D}(-)-\beta$-hydroxybutyric acid clearance of $139 \pm s=17\left(\mathrm{ml} \cdot \mathrm{kg}^{-1} \cdot \mathrm{min}^{-1}\right)(s=$ standard deviation) for the total ketone bodies $(\beta$ $\mathrm{HOB}+\mathrm{AcAc}$ ) [5]. Blood levels increased linearly with infusion rates up to a dosis of $150 \mu$ moles AcAc per $\mathrm{kg}$ per min. At higher dosage, the turnover was impaired and the blood levels increased more rapidly.

We have compared and analyzed biometrically the relations between infusion rate and blood level increase of ketone bodies in healthy and in diabetic rats. In Fig. 1 the two scatter diagramms are represented by different symbols.

The total clearance calculated from the data of 23 healthy rats was $138 \pm s=18\left(\mathrm{ml} \cdot \mathrm{kg}^{-1} \cdot \mathrm{min}^{-1}\right)$ and agrees closely with that formerly obtained [5]. Within the range of dosage up to $140 \mu$ moles $\cdot \mathrm{kg}^{-1} \cdot \mathrm{min}^{-1}$ we calculated a linear regression between infusion rate $(x)$

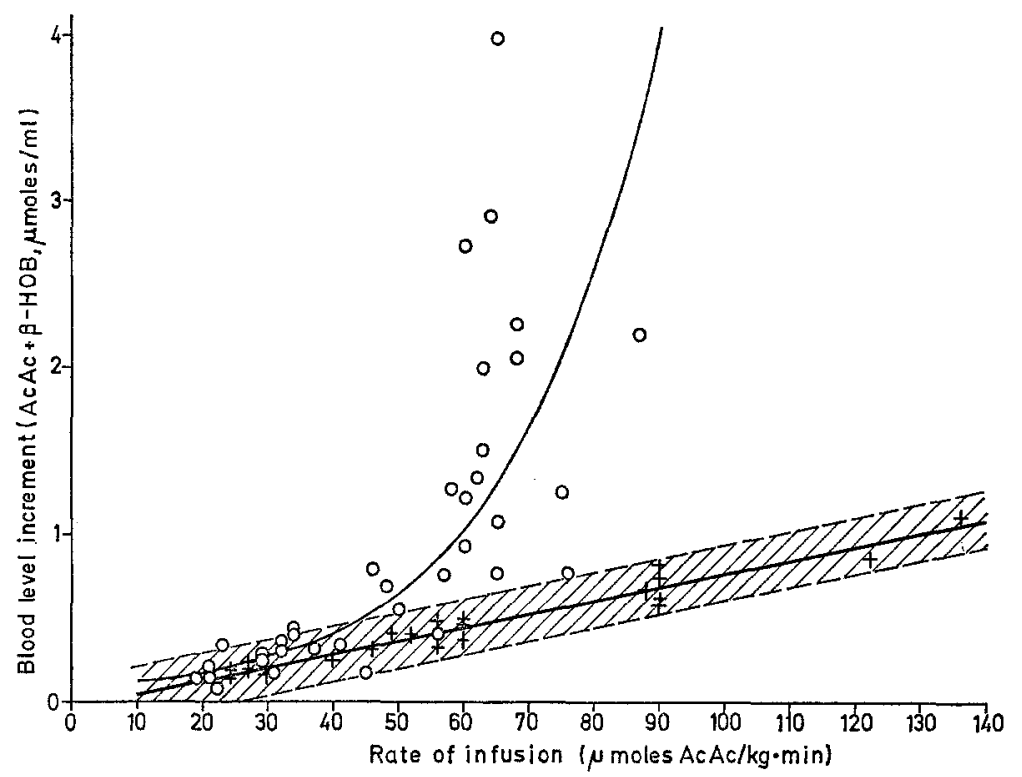

Fig. 1. Relation between infusion rate and blood level increase of ketone bodies in healthy and diabetic rats. ++ blood levels of healthy rats. $\mathrm{O}-\mathrm{o}=$ blood levels of diabetic rats. Experimental arrangement v. "Methods". The hatched zone is the confidence interval for the regression line in healthy rats (1 per cent level of orror)

$(\beta$-HOB) and acetoacetic acid (AcAc) [6]. The infusion went on for six hours. A steady blood level appeared after $2-3 \mathrm{~h}$. This steady state level minus the initial level was plotted against the infusion rate in Fig. 1. Acetoacetic acid was prepared by hydrolysis of the ethyl ester and crystallized as lithium salt [7]. Before the infusion the salt was converted into the free acid by passage through an ion-exchange column of Dowex $50 \mathrm{~W} \times 4$ and then adjusted to $\mathrm{pH} 4.5$ with $\mathrm{NH}_{4} \mathrm{OH}$.

\section{Results}

In the state during continuous i.v. infusions kinetic characteristics and turnover rates can be measured in a quantitative and reproducible way, because the organism is in a balance of supply and elimination [8]. Using this technique in healthy rats we found a total and blood level increase in healthy rats $\left(y_{h}\right)$ following the equation

$$
y_{n}=0.03469+0.00806 x .
$$

By the test of Snedecor [9], the assumed linear model adequately describes the data. The coefficient of correlation is high $(r=0.97)$. The confidence limits for the pairs of values are shown by the hatched zone in the diagram wherein, in comparable investigations, $99 \%$ of all individual observations are to be expected.

The diagram shows that this confidence region is not applicable to the diabetic rats. Up to a dosage of about $50 \mu$ moles $\cdot \mathrm{kg}^{-1} \cdot \mathrm{min}^{-1}$ differences between healthy and diabetic animals cannot be discerned. Within this range the total clearance in the diabetic rats is in the same order of magnitude as in the healthy ones. 
At higher dosages, however, the total clearance diminishes and the blood levels rapidly rise together with increasing variation.

Furthermore, the linear model of regression turns out to be inadequate. Following the analytic procedure described by Weber and Brott [10], the fitting of different polynomials to the data by the method of least squares and the comparisons of the respective residual variances (variances of the deviations of the measured values from the regression lines) gave evidence of highly significant quadratic and cubic components. Hence, a curvilinear regression more adequately fits the data. The assumption of an exponential regression leads to the formula wherein $y_{a}$ gives the blood level increase of the diabetic rats.

$$
y_{d}=0.064 \cdot e^{0.0463 x}
$$

The correlation coefficient which corresponds to this exponential regression (Fig. 1) is high $(r=0.87)$. The changed pattern of elimination of ketone bodies in diabetic rats is combined with poor compatibility.

Table 1. Mean values and standard deviations of total clearance in the specified groups of rats, which received AcAcinfusions with rates between 60 and 80 umoles $\cdot \mathrm{kg}^{-1} \cdot \mathrm{min}^{-1}$

\begin{tabular}{lccc}
\hline Group & $n$ & $\bar{x}_{i}$ & $s_{i}$ \\
\hline I diabetic rats & 17 & 38.5 & 12.3 \\
II diabetic rats treated with & & & \\
insulin & 12 & 134.0 & 18.6 \\
III normal rats & 14 & 128.0 & 21.2 \\
\hline Total & 43 & & \\
\hline
\end{tabular}

Insulin-treatment: Diabetic rats, prepared as described under "methods", received s.c. injections of 5 IU Depot-Insulin Hoechst every $12 \mathrm{~h}$ for $4-6$ days. $n=$ number of animals; $\bar{x}_{i}=$ mean values; $s_{i}=$ standard de viation.
$0.1 \mathrm{IU} \cdot \mathrm{kg}^{-1} \cdot \mathrm{h}^{-1}$ together with the infusion) led to a decrease of the initial levels of ketone bodies and the blood glucose level, but not to an improvement of the ketone body clearance. Obviously there are alterations of enzyme levels which cannot be repaired within a short time.

Chronic treatment with insulin (5 IU Depot-Insulin Hoechst every $12 \mathrm{~h}$ for 4-6 days), however, completely restored the capacity to eliminate ketone bodies. The total clearances of three groups of rats were examined: diabetic rats, diabetic rats with chronic insulin treatment, as described above, and healthy animals. The rats received i.v. infusions with rates between 60 and $80 \mu$ moles $\mathrm{AcAc} \cdot \mathrm{kg}^{-1} \cdot \mathrm{min}^{-1}$. The mean values for the total clearances $\left(\bar{x}_{i}\right)$ and standard deviations $\left(s_{i}\right)$ within the three groups are given in Table 1 . The hypothesis $\bar{x}_{1}=\bar{x}_{2}=\bar{x}_{3}$ was tested by an analysis of variance corresponding to a completely randomized design. From the results given in Table 2 it follows that at least one difference between the three mean values is highly significant. The further analysis of the differences between the three mean values by Scheffé's method showed significant differences between the means of the normal resp. the diabetic group treated with insulin on the one hand versus the diabetic group without treatment on the other hand $(P<1 \%)$, whereas the difference between normal and insulin-treated diabetic rats is not significant. Furthermore no deaths occured during AcAc-infusions in insulin-treated diabetic rats.

\section{Discussion}

On the supposition that the streptozotocin-diabetes in rats can be compared with human diabetes, the experiments provide an explanation of the development of diabetic coma. The changed turnover kinetics do

Table 2. Analysis of variance for the comparison of the mean values of total clearances in three groups of rats specified in Table 1

\begin{tabular}{lccrrr}
\hline $\begin{array}{l}\text { Source of } \\
\text { variation }\end{array}$ & $\begin{array}{l}\text { Degrees of } \\
\text { freedom }\end{array}$ & $\begin{array}{l}\text { Sum of } \\
\text { squares }\end{array}$ & $\begin{array}{l}\text { Mean } \\
\text { square }\end{array}$ & F-ratio & Significance \\
\hline Among groups & 2 & 87800 & 43900 & $\mathbf{1 4 5 . 6 2 7}$ & $p<0.1 \%$ \\
Within groups & 40 & $\mathbf{1 2 0 5 8}$ & 301 & & \\
Total & 42 & 99858 & & & \\
\hline
\end{tabular}

Whereas we had no deaths in healthy rats with infusion rates up to $150 \mu$ moles $\cdot \mathrm{kg}^{-1} \cdot \mathrm{min}^{-1}$, deaths occurred more frequently in diabetic rats with rising dosages. Up to dosages of $50 \mu$ moles $\cdot \mathrm{kg}^{-1} \cdot \mathrm{min}^{-1}$ there were no deaths and the elimination within this range was normal. At $60 \mu$ moles 40 per cent, between 60 and $70 \mu$ moles 48 per cent, and above $70 \mu$ moles 75 per cent of the diabetic animals died during the third or fourth hour of the infusion.

Acute treatment with insulin (1 IU per kg immediately before the infusion by i.v. injection and then not become evident as long as the production of ketone bodies is small. At production rates of ketone bodies above 50 umoles $\cdot \mathrm{kg}^{-1} \cdot \mathrm{min}^{-1}$, however, the blood levels of ketone bodies increase exponentially to high values, whereas in healthy rats there is still a linear relationship between production and utilization. In the diabetic animals there is apparently a disturbance of the utilization of ketone bodies (as to renal elimination. there are no differences between healthy and diabetic animals) and the high levels of ketone bodies already result from a moderately increased production of ke- 
tone bodies. From the values of the total clearance in healthy rats it can be calculated that in starvation ketosis a blood level of $1.5 \mu$ moles $\beta$-HOB + AcAc per $\mathrm{ml}$ is caused by a production of ketone bodies of $150 \mu$ moles $\cdot \mathrm{kg}^{-1} \cdot \min ^{-1}[5]$. In diabetic animals an equally high blood level is brought about by a production of ketone bodies of about 70 umoles $\cdot \mathrm{kg}^{-1}$. $\min ^{-1}$.

Differing opinions concerning underutilization of ketone bodies in diabetic ketoacidosis can probably be attributed to the fact that the results depend on experimental design as far as the range of blood levels or the rate of production or supply of ketone bodies are concerned - as Fig. 1 clearly shows.

The enzymatic basis for the impaired utilization described above has not yet been elucidated and has to be examined.

Acknowledgements. We thank the "Jacques Pfrimmer Gedächtnisstiftung" in Erlangen for the support of this work. - Streptozotocin was a gift from the Upjohn GmbH., Heppenheim (Bergstraße).

\section{References}

1. Krebs, H.A.: The regulation of the release of ketone bodies by the liver. Advances in Enzyme Regulation, Vol. 4, p. 339-353. Oxford, London: Pergamon Press 1966.
2. Wieland, O.: Ketogenesis and its regulation. Advances in metabolic disorders, Vol. 3, p. 1-47. New York, London: Academic Press 1968.

3. Williamson, J.R.: Effects of fatty acids, glucagon, and anti-insulin serum on the control of gluconeogenesis and ketogenesis in rat liver. Advances in enzyme regulation, Vol. 5, p. 229-255. Oxford, London: Pergamon Press 1967.

4. Cahill, G.F., jr., Owen, O.E.: Some observations on carbohydrate metabolism in man. Carbohydrate meta. bolism and its disorders, Vol. 1, p. 497-522. New York, London: Academic Press 1968.

5. Bässler, K.H., Wagner, G., Heicke, B.: Dynamik des Ketonkörperstoffwechsels bei gesunden Ratten. $Z$. ges. exp. Med. 153, 131-133 (1970).

6. Stein, G., Bässler, K.H.: Mikromethode zur enzymatischen Bestimmung von Acetessigsäure und D-(-) $-\beta$ Hydroxybuttersäure in Blut und Geweben. Z. klin. Chem. 6, 27-30 (1968).

7. Hall, L.M.: Preparation of crystalline lithium acetoacetate. Analyt. Biochem. 3, 75-80 (1962).

8. Dost, F.H. : Grundlagen der Pharmakokinetik. Stuttgart: Thieme 1968

9. Snedecor, G.W.: Statistical methods, 5 th edition. Ames, Iowa: Iowa State Unjversity Press 1961.

10. Weber, E., Brott, C.: Ein Linearitätstest mit Hilfe elektronischer Datenverarbeitungsanlagen. Biometr. Z. 5, 188-205 (1963).

Prof, Dr. K.H. Bässler

2. Lehrstuhl Physiologische Chemie D-6500 Mainz

Langenbeckstr. 1

Germany 